Article

\title{
Impact of Endocytosis and Lysosomal Acidification on the Toxicity of Copper Oxide Nano- and Microsized Particles: Uptake and Gene Expression Related to Oxidative Stress and the DNA Damage Response
}

\author{
Bettina Maria Strauch, Wera Hubele and Andrea Hartwig *(D) \\ Department of Food Chemistry and Toxicology, Institute of Applied Biosciences (IAB), \\ Karlsruhe Institute of Technology (KIT), 76131 Karlsruhe, Germany; bettina_strauch@gmx.de (B.M.S.); \\ W.Hubele@gmx.de (W.H.) \\ * Correspondence: Andrea.Hartwig@kit.edu; Tel.: +49-721-60847645
}

Received: 6 February 2020; Accepted: 30 March 2020; Published: 3 April 2020

\begin{abstract}
The toxicity of the copper oxide nanoparticles ( $\mathrm{CuO} \mathrm{NP}$ ) has been attributed to the so-called "Trojan horse"-type mechanism, relying on the particle uptake and extensive intracellular release of copper ions, due to acidic $\mathrm{pH}$ in the lysosomes. Nevertheless, a clear distinction between extra- and intracellular-mediated effects is still missing. Therefore, the impact of the endocytosis inhibitor hydroxy-dynasore (OH-dyn), as well as bafilomycin A1 (bafA1), inhibiting the vacuolar type $\mathrm{H}^{+}$-ATPase (V-ATPase), on the cellular toxicity of nano- and microsized $\mathrm{CuO}$ particles, was investigated in BEAS 2 B cells. Selected endpoints were cytotoxicity, copper uptake, glutathione (GSH) levels, and the transcriptional DNA damage and (oxidative) stress response using the high-throughput reverse transcription quantitative polymerase chain reaction (RT-qPCR). OH-dyn markedly reduced intracellular copper accumulation in the cases of $\mathrm{CuO} \mathrm{NP}$ and $\mathrm{CuO} \mathrm{MP}$; the modulation of gene expression, induced by both particle types affecting especially HMOX1, HSPA1A, MT1X, SCL30A1, IL8 and GADD45A, were completely abolished. BafA1 lowered the intracellular copper concentration in case of $\mathrm{CuONP}$ and strongly reduced transcriptional changes, while any $\mathrm{CuO} \mathrm{MP}$-mediated effects were not affected by bafA1. In conclusion, the toxicity of $\mathrm{CuO}$ NP depended almost exclusively upon dynamin-dependent endocytosis and the intracellular release of redox-active copper ions due to lysosomal acidification, while particle interactions with cellular membranes appeared to be not relevant.
\end{abstract}

Keywords: copper oxide nanoparticles; genomic stability; gene expression profiling; high-throughput RT-qPCR; endocytosis; cellular copper uptake; lysosomal acidification; Trojan horse-type mechanism

\section{Introduction}

Copper oxide nanoparticles (CuO NP) are increasingly applied as catalysts, additives in plastics, or as antimicrobial agents [1]. Thus, a detailed toxicological knowledge is important as a prerequisite to ensure an appropriate risk assessment due to enhanced exposure and the potential risk of adverse health effects, especially with respect to occupational exposure. Pronounced cytotoxic and genotoxic effects of $\mathrm{CuO} \mathrm{NP}$, compared to other metal-based nanoparticles, bigger counterparts of the same chemical composition, as well as water soluble copper compounds, was repeatedly demonstrated in various cell culture models. As an underlying reason, a CuO NP-induced intracellular copper overload was reported and proposed to be most decisive for adverse reactions [2-8], named as the "Trojan horse" mechanism $[2,9]$. 
According to this theory, the particles are taken up via endocytic pathways, delivering large amounts of $\mathrm{CuO}$ within vesicles, which are further processed into acidic lysosomes, leading to an enhanced dissolution of the particles, and resulting in an extensive intracellular overload with copper ions. Thus, strict homeostatic control of copper uptake via transporters like high-affinity copper transporter 1 (hCTR1) is bypassed, and redox-active copper ions provoke the oxidative stress induced by hydroxyl radicals via Fenton-type reactions, causing oxidative damage to DNA, lipids and proteins [10]. Furthermore, the high thiol affinity of copper ions turns redox-sensitive cysteines, present for example in zinc-binding protein structures, but also in the active sites of several enzymes, into important targets of copper toxicity. Accordingly, the modulation of zinc-binding structures which are present in several DNA repair and tumor suppressor proteins, but also in redox-regulated transcription factors, may lead to an interference with the DNA damage response system, either directly or indirectly via ROS as second messengers; this may further contribute to the toxicity of CuO NP [11,12]. The modulation of gene expression by $\mathrm{CuO} \mathrm{NP}$ was investigated in detail in a previous study of our working group in adenocarcinoma A549 and BEAS-2B lung cells [8]. Gene expression profiling was performed by a high-throughput reverse transcription quantitative polymerase chain reaction (RT-qPCR) technique, quantifying the impact of 96 samples in parallel on the expression of 95 genes crucial for maintaining genomic stability. Selected genes were related to metal homeostasis, an (oxidative) stress response as well as DNA repair, cell cycle regulation and apoptosis [13]. A pronounced dose-dependent impact on copper uptake, an oxidative stress response, DNA damage response and apoptosis-associated genes, was observed in case of the $\mathrm{CuO} \mathrm{NP}$, concomitant with a distinct copper overload in the cytoplasm, and especially the nucleus. Far weaker effects were observed after treatment with micro-sized $\mathrm{CuO}$ particles, or with water-soluble copper chloride. Furthermore, along with the marked activation of the DNA damage response on the transcriptional level, concentration-dependent cytotoxicity, the induction of oxidative stress, cell cycle arrest, and apoptosis, were observed by $\mathrm{CuONP}$ on the functional level in BEAS-2B cells [8].

Following up on these observations, different aspects still need to be clarified. Even though the observations may well be explained by a Trojan horse-type mechanism described above, a clear link, as well as the exclusion of other direct cellular interactions of the NP, are still missing. Supporting evidence is provided by the demonstration of $\mathrm{CuO}$ NP uptake via different endocytic pathways [14-18]. Nevertheless, the distinction between the potential effects induced by the particles extracellularly, e.g., via interactions with membrane receptors, and effects arising due to intracellular copper ion release in acidic lysosomes, remains to be established.

Therefore, within the present study, the impact of the dynamin-dependent endocytosis inhibitor hydroxy-dynasore (OH-dyn) $[19,20]$, and the specific inhibitor of the vacuolar type $\mathrm{H}^{+}$-ATPase (V-ATPase) bafilomycin A1 (bafA1) (which prevents lysosomal acidification [21,22]), on the cellular copper uptake, cytotoxicity, and especially the modulation of gene expression by $\mathrm{CuO} \mathrm{NP}$, was investigated. Since the lung is the major target of $\mathrm{CuO} N P$ toxicity, experiments were performed in epithelial bronchial non-tumorigenic BEAS-2B cells, widely used for mechanistic in-vitro studies associated with lung toxicity, including lung carcinogenesis, and well suited for NP-induced gene expression analyses [8]. The effects of $\mathrm{CuO} \mathrm{NP}$ were compared to $\mathrm{CuO} \mathrm{MP}$ and water-soluble $\mathrm{CuCl}_{2}$ to distinguish between the particle, nanoparticle or copper ion-mediated effects, and to identify potential unspecific or side-effects of the inhibitor substances.

Our results confirmed a relevant participation of dynamin-dependent endocytosis in the uptake of $\mathrm{CuO} \mathrm{NP}$ and $\mathrm{CuO} \mathrm{MP}$ by the use of $\mathrm{OH}$-dyn. Furthermore, bafA1 was effective in preventing $\mathrm{CuO}$ NP-induced cytotoxicity and glutathione (GSH) depletion, coincident with decreased intracellular copper accumulation assumed to result from the stalled uptake of $\mathrm{CuO} \mathrm{NP}$, and thus diminishing the release of redox-reactive copper ions in less acidic lysosomes. The gene expression analyses confirmed that the CuO NP-mediated modulation of gene expression greatly depends on both endocytosis and lysosomal acidification, and consequently on intracellular copper ion release. 


\section{Materials and Methods}

\subsection{Materials}

Chemicals, including agarose, salts, glycerol, leupeptine, phenylmethanesulfonyl-fluoride (PMSF), bovine serum albumin, acids, snap-on lid glasses and stirring bars, were obtained from Carl Roth GmbH (Karlsruhe, Germany). CuO NP (\#544868, Lot \#MKAA0633), CuO MP (\#208841, Lot \#MKAA1788) and copper chloride were purchased from Sigma-Aldrich Chemie GmbH (Steinheim, Germany). All PCR consumables, including PCR tubes, strips and reaction tubes and tubules, as well as cell culture dishes and flasks, were obtained from Sarstedt (Nuembrecht, Germany). The primer pairs were synthesized by Eurofins (Ebersberg, Germany) or Fluidigm (San Francisco, CA, USA). OH-dyn, Dulbecco's modified Eagle's medium (DMEM), dimethyl sulfoxide (DMSO), trypsin, amphotericin B, trypsin inhibitor from glycine max (soybean) (SBTI) and penicillin-streptomycin solutions are products of Sigma-Aldrich. Fetal calf serum (FCS) and LHC-9 media are products of Invitrogen GmbH (Darmstadt, Germany). BafA1 was purchased from Santa Cruz Biotechnology (Heidelberg, Germany). Human fibronectin was obtained from Biopur (Reinach, Switzerland) and collagen from Roche (Mannheim, Germany). DNA suspension buffer, PCR-certified water and TE buffer were obtained from Teknova (Hollister, CA, USA). 2X Assay Loading Reagent and 20X DNA Binding Dye Sample Loading Reagent were purchased from Fluidigm (San Francisco, CA, USA). Bio-Rad (Munich, Germany) provided the 2X SsoFastTM EvaGreen ${ }^{\circledR}$ Supermix with Low ROX and the 2X SYBR Green Supermix. The 2X TaqMan ${ }^{\circledR}$ PreAmp Master Mix was obtained from Applied Biosystems (Darmstadt, Germany) and the exonuclease I from New England Biolabs (Frankfurt am Main, Germany).

\subsection{Particle and $\mathrm{CuCl}_{2}$ Incubation Suspensions and Dilutions}

Fresh $\mathrm{CuO} N \mathrm{NP}$ and $\mathrm{CuO} \mathrm{MP}$ suspensions, as well as $\mathrm{CuCl}_{2}$ dilutions, were prepared for each experiment. Particles, received as dry powder, were aliquoted by weighing into $1.5 \mathrm{~mL}$ polystyrene reaction tubes. Stock solutions of $1 \mathrm{mg} / \mathrm{mL} \mathrm{CuO}$ were prepared in an endotoxin-free snap-on glass, containing a stirring bar in DMEM containing 10\% FCS. Dilutions in the range of 5, 10, 20 and 50 $\mu \mathrm{g} / \mathrm{mL}$ were prepared by adding aliquots of the stirring stock solution into snap-on lid glasses filled with adequate volumes of fresh medium. Stirring took place at $900 \mathrm{rpm}$ and room temperature on a multiphase stirrer (Variomag Poly, Carl Roth $\mathrm{GmbH}$, Karlsruhe, Germany). $\mathrm{CuCl}_{2}$ was dissolved in bi-distilled $\mathrm{H}_{2} \mathrm{O}(100 \mathrm{mM})$ and sterile-filtered. The dilution to $630 \mu \mathrm{M}$ corresponding to $50 \mu \mathrm{g} / \mathrm{mL} \mathrm{CuO}$ was prepared from the stock solution by dilution in an adequate amount of DMEM containing $10 \%$ FCS directly before incubation. Based on the copper content, $1 \mu \mathrm{g} / \mathrm{mL} \mathrm{CuO}$ is equal to $0.2 \mu \mathrm{g} / \mathrm{cm}^{2} \mathrm{CuO}$ and $12.6 \mu \mathrm{M} \mathrm{Cu}^{2+}$ in case of complete dissolution.

\subsection{Cell Culture and Incubation}

Human lung bronchial epithelial BEAS-2B cells (ATCC CRL-9609), immortalized with SV40 large T-antigen, were kindly provided by Dr. Carsten Weiss (Karlsruhe Institute of Technology, Karlsruhe, Germany). They were grown as monolayers in coated cell culture dishes $\left(100 \mathrm{~mm}, 58 \mathrm{~cm}^{2}\right.$, coated with $10 \mu \mathrm{g} / \mathrm{mL}$ human fibronectin, $30 \mu \mathrm{g} / \mathrm{mL}$ collagen and $10 \mu \mathrm{g} / \mathrm{mL}$ bovine serum albumin in phosphate-buffered saline (PBS)) in $12 \mathrm{~mL}$ LHC-9 medium containing $2.5 \mu \mathrm{g} / \mathrm{mL}$ amphotericin B. Cells were incubated at $37{ }^{\circ} \mathrm{C}$ in a humidified atmosphere of $5 \% \mathrm{CO}_{2}$ in air. For all of these experiments, the cells were seeded at a density of 16,600 cells $/ \mathrm{cm}^{2}$. After $48 \mathrm{~h}$ the supernatant was removed from the logarithmically growing cells, and replaced by the particle or $\mathrm{CuCl}_{2}$ incubation suspensions $\left(0.2 \mathrm{~mL} / \mathrm{cm}^{2}\right)$ in DMEM containing 10\% FCS, as described for the respective experiments. For co-incubation with the endocytosis inhibitor, BEAS-2B cells were pre-incubated with $100 \mu \mathrm{M}$ $\mathrm{OH}$-dyn for $30 \mathrm{~min}$, and afterwards co-treated with $\mathrm{CuO} \mathrm{NP}, \mathrm{CuO} \mathrm{MP}$ or $\mathrm{CuCl}_{2}$ and $\mathrm{OH}$-dyn for $8 \mathrm{~h}$. Co-incubation of the copper compounds with $100 \mathrm{nM}$ bafA1 occurred for $24 \mathrm{~h}$ without pre-treatment.

Since stock solutions of $\mathrm{OH}$-dyn $(20 \mathrm{mM})$ and bafA1 $(50 \mu \mathrm{M})$ were prepared in DMSO, the same amount of DMSO was added to the respective controls without the inhibitor substances. 


\subsection{Cell Number}

Logarithmically growing BEAS-2B cells were incubated for $24 \mathrm{~h}$ with $10 \mu \mathrm{g} / \mathrm{mL} \mathrm{CuO} \mathrm{NP}, 50 \mu \mathrm{g} / \mathrm{mL}$ $\mathrm{CuOMP}$ or $630 \mu \mathrm{M} \mathrm{CuCl}_{2}$, with or without $100 \mathrm{nM}$ bafA1 or $100 \mu \mathrm{M} \mathrm{OH}$-dyn, respectively, trypsinized and collected in DMEM containing 10\% FCS. Cell number was determined via Casy ${ }^{\circledR}$ cell counter (OLS OMNI Life Science GmbH and Co. KG, Bremen, Germany).

\subsection{Gene Expression Analyses}

0.5-1 $\times 10^{6}$ logarithmically growing BEAS-2B cells were treated with different concentrations of $\mathrm{CuONP}, \mathrm{CuOMP}$ or $\mathrm{CuCl}_{2}$, with or without $100 \mu \mathrm{MOH}$-dyn or $100 \mathrm{nM}$ bafA 1 for $8 \mathrm{~h}$ or $24 \mathrm{~h}$, respectively, in DMEM containing 10\% FCS. Subsequently, gene expression analyses via high-throughput RT-qPCR with Fluidigm dynamic arrays on the BioMarkTM System were performed, as described previously [13]. For normalization, five potential reference genes were available ( $A C T B, B 2 M, G A P D H, G U S B$ and HPRT1). Finally, potential alterations of the transcript levels of the target genes under investigation were displayed as fold change compared to the respective control group, by calculating relative quantities corresponding to the $\Delta \Delta \mathrm{Cq}$ method [23].

\subsection{Cellular Copper Uptake}

Logarithmically growing BEAS-2B cells were treated with $10 \mu \mathrm{g} / \mathrm{mL} \mathrm{CuO} \mathrm{NP,50 \mu g/mL} \mathrm{CuO}$ $\mathrm{MP}$ or $630 \mu \mathrm{M} \mathrm{CuCl}_{2}$, with or without $100 \mu \mathrm{M} \mathrm{OH}$-dyn or $100 \mathrm{nM}$ bafA1, respectively, for $8 \mathrm{~h}$ or $24 \mathrm{~h}$, respectively, in DMEM containing 10\% FCS. The cells were trypsinized, collected in ice-cold PBS containing 10\% FCS, and washed twice with PBS. Cell number and cell volume were determined via Casy ${ }^{\circledR}$ cell counter. To quantify the intracellular copper levels in the soluble cell fractions, and thus to eliminate particles attached at the outer cell membrane, the cells were lysed in radioimmunoprecipitation assay (RIPA) buffer (0.01 M Tris pH 7.6, 0.15 M NaCl, 0.001 M ethylenediaminetetraacetic acid (EDTA), $1 \%(v / v)$ Trition-X 100, 1\% (v/v) desoxycholic acid, sodium salt, $0.01 \%$ sodium dodecyl sulfate (SDS) $0.001 \mathrm{M}$ phenylmethylsulfonyl fluoride (PMSF), $1 \times$ protease-inhibitor mixture) for 30 min before centrifugation at $14,000 \times \mathrm{g}\left(1 \mathrm{~h}, 4^{\circ} \mathrm{C}\right)$, thereby precipitating the cell membranes. The supernatant contained the soluble cell fraction of both the cytoplasm and nucleus, and its copper content was determined using GF-AAS (Perkin Elmer Atomic Absorption Spectrometer PinAAcle 900T, Rodgau, Germany). The solution was evaporated at $95{ }^{\circ} \mathrm{C}$, incubated with ashing mixture, $65 \% \mathrm{HNO}_{3} / 30 \%$ $\mathrm{H}_{2} \mathrm{O}_{2}(1 / 1)$, evaporated at $95^{\circ} \mathrm{C}$ again, and resolved in water. Copper content was normalized to cell number and cell volume.

\subsection{Quantification of Intracellular Glutathione}

The quantification of intracellular glutathione levels was performed according to the method established by Tietze et al. [24]. Briefly, logarithmically growing BEAS-2B cells were incubated for $2 \mathrm{~h}$ with $10 \mu \mathrm{g} / \mathrm{mL} \mathrm{CuO} \mathrm{NP}$, with or without $100 \mathrm{nM}$ BafA1, respectively, in DMEM containing 10\% FCS. The cells were trypsinized, collected in ice-cold PBS containing 10\% FCS, washed with PBS, analyzed via Casy ${ }^{\circledR}$ cell counter for cell number and cell volume and collected by centrifugation. $1 \times 10^{6}$ cells were collected in $\mathrm{KP}$ buffer $\left(0.1 \mathrm{M} \mathrm{KH}_{2} \mathrm{PO}_{4}, 0.1 \mathrm{M} \mathrm{K}_{2} \mathrm{HPO}_{4}, 1 \mathrm{mM}\right.$ EDTA, pH 7.4). Cells were lyzed by 2 freeze-and-thawing cycles followed by sonification, acidification with sulphosalicyclic acid and vortexing. Cells were centrifuged at $16,000 \mathrm{rpm}$ for $20 \mathrm{~min}$ at $4{ }^{\circ} \mathrm{C}$ prior to measuring total GSH in the supernatant by reducing oxidized GSH content using GR enzyme $(4 \mathrm{U} / \mathrm{mL})$ and the reduced form of nicotinamide adenine dinucleotide phosphate (NADPH) (0.3 mM). GSH reacts with 5,5'-dithiobis-2-nitrobenzoic acid (DTNB) to form 2-nitro-5-thiobenzoate (TNB). The change in TNB absorbance was measured at $412 \mathrm{~nm}$ using a plate reader (Tecan). Data were compared to GSH standard calibration curves and normalized to cell volume. 


\subsection{Statistics}

Differences between control and treated samples were analyzed by one-way analysis of variance (ANOVA), followed by Dunnett's T post hoc test, and the differences between the different incubation conditions with and without $\mathrm{OH}-\mathrm{dyn}$ or bafA1 were analysed by T-test, respectively.

\section{Results}

\subsection{Particle Characteristics}

Particle characteristics are summarized in Table 1. CuO NP and CuO MP were characterized using DLS with respect to size, scanning electron microscopy (SEM) for size and morphology, Brunauer-Emmett-Teller (BET) for surface area, zeta potential (ZP) for surface charge, inductively coupled plasma mass spectrometry (ICP-MS), Energy-dispersive X-ray spectroscopy (EDX) and oxygen analysis for purity and composition, as well as X-ray diffraction (XRD) for crystallinity in two previous studies of our working group. Additionally, the impact on $\mathrm{pH}$ in relevant media and solubility in different fluid models, like DMEM containing 10\% FCS and lysosomal artificial fluid (ALF), was investigated. Briefly, both $\mathrm{CuO}$ particles were of high purity ( $>99.8 \%$ ), of equal composition, were free of endotoxins, and did not alter the $\mathrm{pH}$ of the cell culture media. $\mathrm{CuO} \mathrm{NP}$ were approximately spherical, displayed a narrow size range (20-200 nm, with a calculated average diameter of $55 \mathrm{~nm}$ based on the specific surface area, and $146 \mathrm{~nm}$ in cell culture medium containing 10\% FCS derived from the DLS measurements), a surface area of $17.23 \mathrm{~m}^{2} / \mathrm{g}$, and a ZP of $-13.1 \mathrm{mV}$ in DMEM/FCS [7]. About $90 \%$ of the particles were in the range $<100 \mathrm{~nm}$ (Hufnagel and Hartwig, unpublished results). CuO MP showed a size distribution of $500 \mathrm{~nm}-10 \mu \mathrm{m}(1289 \mathrm{~nm}$ calculated average diameter, DLS analysis was not feasible because of fast sedimentation), and a surface area of $0.74 \mathrm{~m}^{2} / \mathrm{g}$ [7].

Table 1. Characterization of the applied $\mathrm{CuO}$ particles (summarized from reference [7]).

\begin{tabular}{cccccc}
\hline Particles & $\begin{array}{c}\text { Size Range } \\
\mathbf{( n m )}\end{array}$ & $\begin{array}{c}\text { Primary Particle } \\
\text { Size }(\mathbf{n m})\end{array}$ & SSA $\left(\mathbf{m}^{2} / \mathbf{g}\right)$ & $\begin{array}{c}\text { Hydrodynamic } \\
\text { Size }(\mathbf{n m})\end{array}$ & $\begin{array}{c}\zeta \text {-potential } \\
(\mathbf{m V})\end{array}$ \\
\hline $\mathrm{CuONP}$ & $\begin{array}{c}20-200 \\
(\mathrm{TEM})\end{array}$ & $55^{*}$ & 17.23 & $(\mathrm{DMEM} / \mathrm{FCS})$ & $\begin{array}{c}-13.1 \\
(\mathrm{DMEM} / \mathrm{FCS})\end{array}$ \\
\hline $\mathrm{CuO} \mathrm{MP}$ & $\begin{array}{c}500-10,000 \\
(\mathrm{TEM})\end{array}$ & $1289 *$ & 0.74 & $\mathrm{nd}^{* *}$ & $\mathrm{nd}^{* *}$ \\
\hline
\end{tabular}

TEM: transmission electron microscopy, SSA: surface specific area, ${ }^{*}$ calculated based on SSA, ${ }^{* *}$ not determined due to rapid sedimentation of the particles.

The solubilities of both particle types have been investigated in our previous study in several model fluids in a time-dependent manner, quantified by graphite furnace atomic absorption spectroscopy (GF-AAS) [7], including artificial alveolar fluid (AAF, $\mathrm{pH}=7.4$, composed as described by Stopford and coworkers [25]) and artificial lysosomal fluid (ALF; $\mathrm{pH}=4.5$, composed as described by Midander and coworkers [26]). In $\mathrm{H}_{2} \mathrm{O}$ and $\mathrm{AAF}$, dissolution for both particles types was below $2.4 \%$, with $\mathrm{CuO}$ $\mathrm{NP}$ releasing more copper ions than the $\mathrm{CuO} \mathrm{MP}$. Nevertheless, the dissolution of CuO NP was highly accelerated in a time-dependent manner in the cell culture medium (DMEM) supplemented with FCS, reaching $44 \%$ after $24 \mathrm{~h}$. In contrast, copper ion release from the CuO MP remained low with $4 \%$ dissolved copper after $24 \mathrm{~h}$ incubation. The accelerated solubility of the $\mathrm{CuO} \mathrm{NP}$ as compared to the $\mathrm{CuO} \mathrm{MP}$ was even more pronounced in the acidic environment of ALF, where $68 \%$ of the CuO NP was already solubilized after $30 \mathrm{~min}$, and after $2 \mathrm{~h}$ dissolution was almost complete. In contrast, $\mathrm{CuO} \mathrm{MP}$ revealed only $10 \%$ dissolution after $4 \mathrm{~h}$, and about $80 \%$ solubilization was reached only after $168 \mathrm{~h}$ [7].

\subsection{Cytotoxicity}

The cell number of BEAS-2B cells was determined as a measure of the cytotoxicity of CuO NP, $\mathrm{CuO} \mathrm{MP}$ and $\mathrm{CuCl}_{2}$ after $24 \mathrm{~h}$ incubation (Figure 1). This approach was chosen due to the inability 
of BEAS 2B cells to form colonies, and a reported interference by copper-based particles and copper ions with dye-based toxicity assays [27]. A detailed investigation on the cytotoxicity of the copper compounds was performed in our previous study, revealing a pronounced concentration-dependent impact of $\mathrm{CuO} N \mathrm{NP}$ upon cell number, starting at $5 \mu \mathrm{g} / \mathrm{mL}$ and reaching $10 \%$ viability in case of 50 $\mu \mathrm{g} / \mathrm{mL}$, a moderate cytotoxic impact in case of $\mathrm{CuO} \mathrm{MP}$, and only weak cytotoxicity in case of $\mathrm{CuCl}_{2}[8]$. Based on these findings, in the present study single concentrations of the respective compounds were selected and analyzed again for cytotoxicity; the results highly corresponded to the previous findings. Cytotoxicity studies were also performed with the dynamin-dependent endocytosis inhibitor hydroxy-dynasore (OH-dyn), as well as with the vacuolar $\mathrm{H}^{+}$-ATPase inhibitor bafA1, applying 100 $\mu \mathrm{M}$ or $100 \mathrm{nM}$, respectively, based on literature data ([19-22]). In the case of bafA1, applying $100 \mathrm{nM}$, almost no reduction in cell number was observed when following the usual protocol of $24 \mathrm{~h}$ used for co-incubation with the $\mathrm{CuO}$ particles (Figure 1). However, in case of $100 \mu \mathrm{M} \mathrm{OH}$-dyn, the $24 \mathrm{~h}$ treatment resulted in only $60 \%$ residual viability compared to the control; therefore the incubation time was reduced to $8 \mathrm{~h}$ in this case in subsequent experiments.

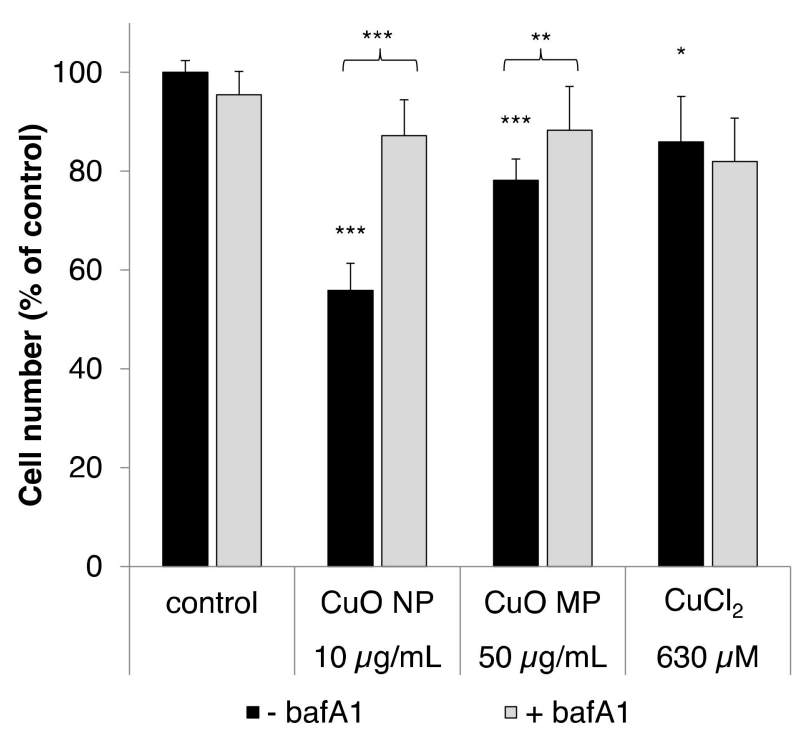

Figure 1. Cytotoxicity of copper oxide nanoparticles ( $\mathrm{CuO} \mathrm{NP}$ ), copper oxide microparticles (CuO MP) and $\mathrm{CuCl}_{2}$ in the absence or presence of bafA1. Cytotoxicity was determined via cell number after $24 \mathrm{~h}$ treatment, with the different copper compounds co-treated with or without bafA1, respectively. Shown are mean values of five determinations derived from three independent experiments + standard deviation (SD). Statistically significant different from control or the respective copper compound treatment: ${ }^{*} p \leq 0.05,{ }^{* *} p \leq 0.01,{ }^{* * *} p \leq 0.001$ (T-test). Based on the copper content, $50 \mu \mathrm{g} / \mathrm{mL} \mathrm{CuO}$ are equal to $630 \mu \mathrm{M} \mathrm{Cu}^{2+}$.

As shown in Figure 1, $10 \mu \mathrm{g} / \mathrm{mL} \mathrm{CuO} \mathrm{NP} \mathrm{exerted} \mathrm{the} \mathrm{most} \mathrm{pronounced} \mathrm{cytotoxicity,} \mathrm{leading} \mathrm{to} \mathrm{a}$ decrease of cell number to $56 \%$ compared to our control. In contrast, $\mathrm{CuO} \mathrm{MP}$ and $\mathrm{CuCl}_{2}$ were far less cytotoxic, even though applied at 5-fold higher mass doses; thus, CuO MP decreased the cell number to $78 \%$ and $\mathrm{CuCl}_{2}$ to $86 \%$. In the presence of the vacuolar $\mathrm{H}^{+}$-ATPase inhibitor bafA1, the cytotoxicity of the $\mathrm{CuO}$ particles was almost completely abolished, most strikingly in case of the $\mathrm{CuO} \mathrm{NP}$, but also in case of the $\mathrm{CuO}$ MP. Thus, the cell number was recovered to about $90 \%$ in both cases. However, no effect of bafA1 on the cytotoxicity of $\mathrm{CuCl}_{2}$ was observed, excluding unspecific interactions.

\subsection{Cellular Copper Uptake}

Cellular copper uptake by $\mathrm{CuO} \mathrm{NP}, \mathrm{CuO} \mathrm{MP}$ and $\mathrm{CuCl}_{2}$ was analyzed via graphite furnace atomic absorption spectroscopy (GF-AAS). As described in Materials and Methods, we applied a special post-incubation procedure, where the plasma membrane was removed to avoid any overestimation 
of intracellular copper levels due to an incomplete elimination of particles from the cellular surface, and thus quantified copper levels within the soluble cell fraction. Within our previous study, $\mathrm{CuO} \mathrm{NP}$ were found to result in a pronounced dose-dependent intracellular copper overload up to millimolar concentrations, while $\mathrm{CuCl}_{2}$ showed the lowest and almost constant copper levels up to $400 \mu \mathrm{M}$ independent from the applied dose. CuO MP resulted in intermediate but also concentration-dependently increased copper levels [8]. Within the present study, the intracellular copper content was investigated after $8 \mathrm{~h}$ incubation in the absence or presence of the dynamin-dependent endocytosis inhibitor OH-dyn (Figure 2A), as well as after $24 \mathrm{~h}$ in the absence or presence of bafA1 (Figure 2B). The shorter co-incubation time in case of OH-dyn was chosen due to its high cytotoxicity after $24 \mathrm{~h}$ treatment, as described above.
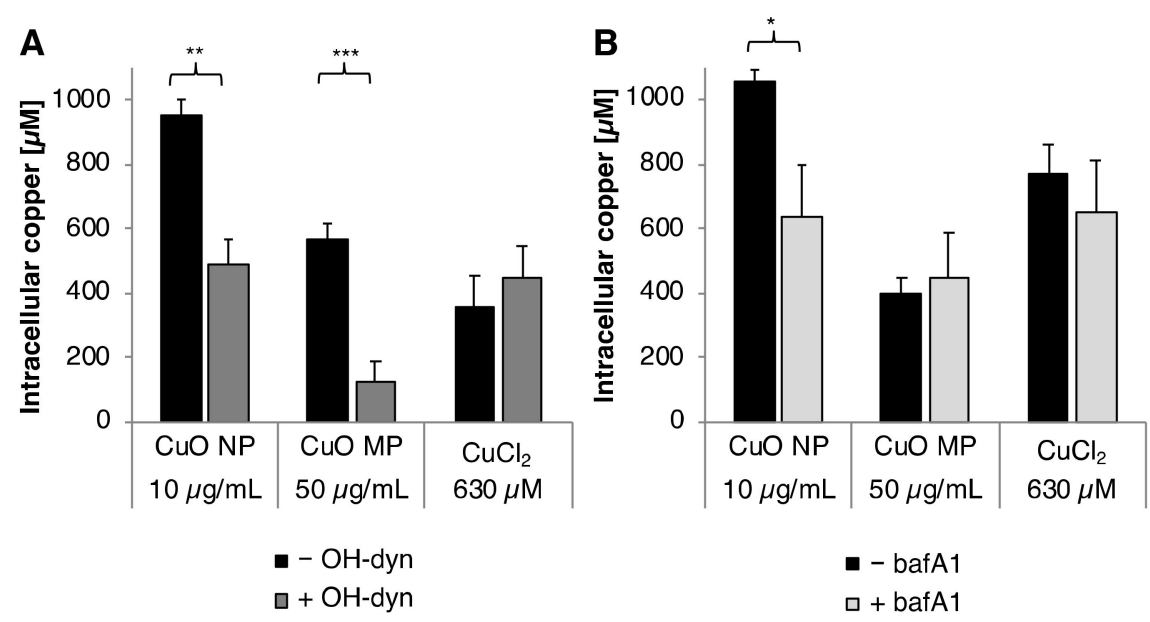

Figure 2. Cellular copper uptake after treatment with $\mathrm{CuO} \mathrm{NP}, \mathrm{CuO} \mathrm{MP}$ or $\mathrm{CuCl}_{2}$ in the presence or absence of (A) OH-dyn and (B) bafA1. Copper content was determined in the soluble fraction of BEAS-2B cells after $8 \mathrm{~h}$ treatment, with the different copper compounds co-treated with or without $\mathrm{OH}-d y n$, or after $24 \mathrm{~h}$ co-treated with or without bafA1, respectively, via GF-AAS. Shown are the mean values of three independent experiments $+\mathrm{SD}$. Statistically significant different from the respective copper compound treatment: ${ }^{*} p \leq 0.05,{ }^{* *} p \leq 0.01,{ }^{* * *} p \leq 0.001$ (T-test). $50 \mu \mathrm{g} / \mathrm{mL} \mathrm{CuO}$ are equal to $630 \mu \mathrm{M} \mathrm{Cu}^{2+}$.

The basal copper concentration in BEAS-2B cells was found to be $20 \mu \mathrm{M}$. After $8 \mathrm{~h}$ incubation, treatment with $\mathrm{CuO} N P$ resulted in the highest intracellular copper levels, namely $950 \mu \mathrm{M}$, considerably higher as compared to the $\mathrm{CuO} \mathrm{MP}(560 \mu \mathrm{M})$ or $\mathrm{CuCl}_{2}(360 \mu \mathrm{M})$. Co-treatment with OH-dyn diminished intracellular copper content by about $50 \%$ to $490 \mu \mathrm{M}$ in the case of $\mathrm{CuO} \mathrm{NP}$, and-even more pronounced-by about $80 \%$ to $130 \mu \mathrm{M}$ in case of $\mathrm{CuO}$ MP. No effect of OH-dyn was observed in the case of $\mathrm{CuCl}_{2}$, excluding any unspecific impact of the inhibitor on the homeostatic copper uptake.

After $24 \mathrm{~h}$ incubation, intracellular copper accumulation was comparable to $8 \mathrm{~h}$ in case of $\mathrm{CuO}$ $\mathrm{NP}$ and $\mathrm{CuO} \mathrm{MP}$. However, higher copper concentrations, namely $770 \mu \mathrm{M}$, were observed in case of $\mathrm{CuCl}_{2}$. An impact of bafA1 was restricted to $\mathrm{CuO} \mathrm{NP}$; surprisingly, intracellular copper accumulation was markedly reduced by $60 \%$ from $1050 \mu \mathrm{M}$ to $640 \mu \mathrm{M}$. In contrast, bafA1 did not alter intracellular copper levels in case of $\mathrm{CuO} \mathrm{MP}$ and $\mathrm{CuCl}_{2}$.

\subsection{Intracellular Glutathione (GSH) Level}

Modulation of intracellular GSH level by CuO NP depending on bafA1 was analyzed according to the method established by Tietze [24]. Intracellular GSH content was diminished to $80 \%$ of control after $2 \mathrm{~h}$ treatment with $10 \mu \mathrm{g} / \mathrm{mL} \mathrm{CuO}$. Co-treatment with bafA1 prevented the $\mathrm{CuO}$ NP-induced reduction of intracellular GSH completely (Figure 3). 


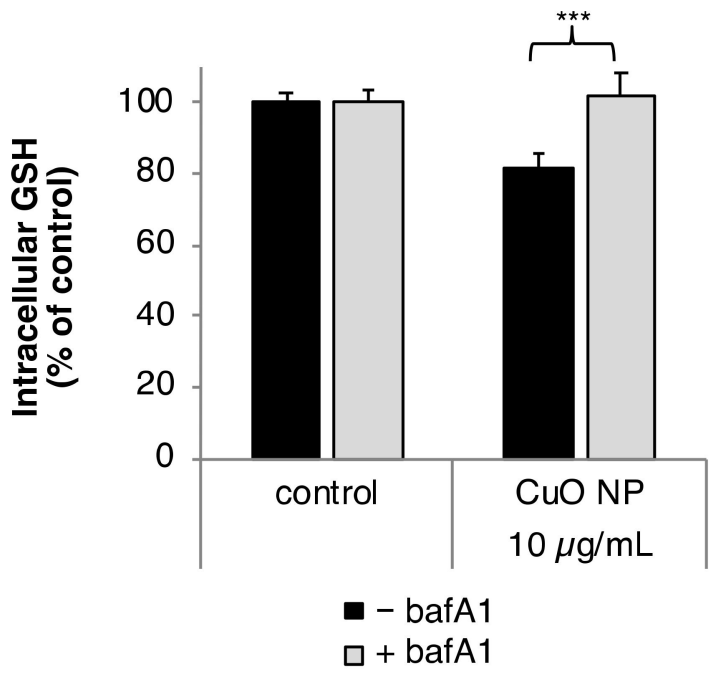

Figure 3. Impact of CuO NP on intracellular glutathione (GSH) level in the presence or absence of bafA1. BEAS-2B cells were treated $\mathrm{CuO}$ NP with or without bafA1 for $2 \mathrm{~h}$. Shown are the mean values of five determinations derived from three independent experiments \pm SD. Statistically significant different from CuO NP treatment: ${ }^{* * *} p \leq 0.001$ (T-test).

\subsection{Gene Expression Analyses}

Gene expression analyses via high-throughput qRT-PCR established previously in our group, quantifying the impact of 96 samples in parallel on the expression of 95 genes crucial for maintaining genomic stability. Selected genes were related to metal homeostasis, (oxidative) stress response as well as DNA repair, cell cycle regulation and apoptosis; a detailed description including a complete list of genes and respective proteins as well as their assignments to the respective groups has been published [13]. Applying this approach in a previous study in BEAS-2B cells after treatment with $\mathrm{CuO}$ $\mathrm{NP}, \mathrm{CuO} \mathrm{MP}$ as well as $\mathrm{CuCl}_{2}$, revealed a strong induction of copper uptake-related metallothionein genes, oxidative stress sensitive and inflammatory genes, anti-oxidative defense-associated genes, as well as the induction of cell cycle inhibitor gene CDKN1A (p21) and the pro-apoptotic PMAIP1 (Noxa) and TNFRSF10B (DR5). Moreover, we observed a down-regulation of genes coding for important DNA repair proteins, along with the induction of DNA damage inducible genes. The extent of modulation occurred strictly dose-dependent in the case of the particulate $\mathrm{CuO}$ compounds, reflecting the increase in intracellular copper concentrations; effects were far most pronounced in case of $\mathrm{CuO} \mathrm{NP}$, whereas alterations in gene expression after treatment with $\mathrm{CuCl}_{2}$ were restricted to cytotoxic concentrations with disturbed copper homeostasis [8]. Following up on this investigation, within the present work, the impact of $\mathrm{CuO} \mathrm{NP}$ and $\mathrm{CuO} \mathrm{MP}$ on gene expression profiles, related to the DNA damage response in the absence and presence of $\mathrm{OH}$-dyn or bafA1, was investigated after $8 \mathrm{~h}$ or $24 \mathrm{~h}$, respectively. Affected genes, respective proteins, as well as an overview of their functions, are provided in Table 2. 
Table 2. Genes affected in a relevant manner by the $\mathrm{CuO}$ particles in the presence or absence of the inhibitors OH-dyn and/or bafA1.

\begin{tabular}{|c|c|c|}
\hline Gene & Protein & Specific Function \\
\hline GADD $45 A$ & $\begin{array}{l}\text { growth arrest and DNA-damage-inducible, } \\
\text { alpha (GADD45A) }\end{array}$ & DNA damage signaling \\
\hline HMOX1 & heme oxygenase (decycling) 1 (HO1) & heme catabolism; oxidative stress response \\
\hline HSPA1A & heat shock 70kDa protein 1A (hsp70) & chaperone; oxidative stress response \\
\hline IL8 & interleukin 8 (IL8) & chemokine; inflammatory response \\
\hline JUN & jun proto-oncogene (c-jun) & $\begin{array}{l}\text { part of the early response transcription factor } \\
\text { AP-1, cell proliferation }\end{array}$ \\
\hline MT1X, MT2A & $\begin{array}{l}\text { metallothionein 1X (MT1X), metallothionein } \\
\text { 2A (MT2A) }\end{array}$ & metal homeostasis \\
\hline SLC30A1 & $\begin{array}{l}\text { solute carrier family } 30 \text { (zinc transporter), } \\
\text { member } 1 \text { (ZnT1) }\end{array}$ & transcription factor, metal homeostasis \\
\hline TXNRD1 & thioredoxin reductase 1 (TxrR) & selenium metabolism; oxidative stress response \\
\hline GCLC & $\begin{array}{l}\text { glutamate-cysteine ligase, catalytic } \\
\text { subunit (GCL) }\end{array}$ & GSH synthesis, oxidative stress response \\
\hline PMAIP1 & $\begin{array}{l}\text { phorbol-12-myristate-13-acetate-induced } \\
\text { protein } 1 \text { (Noxa) }\end{array}$ & pro-apoptotic gene, member of the bcl-2 family \\
\hline
\end{tabular}

\subsection{Impact of $\mathrm{OH}-\mathrm{dyn}$}

$8 \mathrm{~h}$ treatment with $\mathrm{OH}-\mathrm{dyn}$ itself did already modulate the expression of some of the discussed genes, namely HMOX1, HSPA1A and IL8, albeit to a far lesser extent as compared to CuO NP exposure (Figure S1). Therefore, the effects of the co-treatments were related to the $\mathrm{OH}$-dyn treated control. The impact of $8 \mathrm{~h} \mathrm{OH}$-dyn co-treatment on copper particle-modulated gene expression is summarized in a heat map view, displaying the relative gene expression related to the respective control (Figure 4). Strongest effects, starting at the lowest applied concentration of $5 \mu \mathrm{g} / \mathrm{mL}$, were observed in case of $\mathrm{CuO} N P$ (Figure 4A). Most pronounced inductions were observed in case of the ROS-inducible HMOX1 and HSPA1A genes. Furthermore, mRNA levels of the copper uptake-related genes MT1X and SLC30A1 coding for metallothionein 1 and the zinc transporter ZnT-1, respectively, were induced by $\mathrm{CuO}$ NP. Also, transcription of the DNA damage inducible gene GADD45A, the pro-inflammatory gene IL8, the proto-oncogene JUN and the anti-oxidative defense-associated gene TXNRD1 were enhanced in a strictly dose-dependent manner. In contrast, the modulation of expression occurred to a much lesser extent by $\mathrm{CuO} \mathrm{MP}$, with relevant, dose-dependent effects restricted to HMOX1, HSPA1A, IL8 and SLC30A1 transcript levels, even though up to 5 times higher copper amounts were applied (Figure 4B). Most strikingly, no alterations of gene expression compared to controls were observed after co-treatment with $\mathrm{OH}-d y n$, neither in the case of $\mathrm{CuO}$ NP nor $\mathrm{CuO} \mathrm{MP}$. 

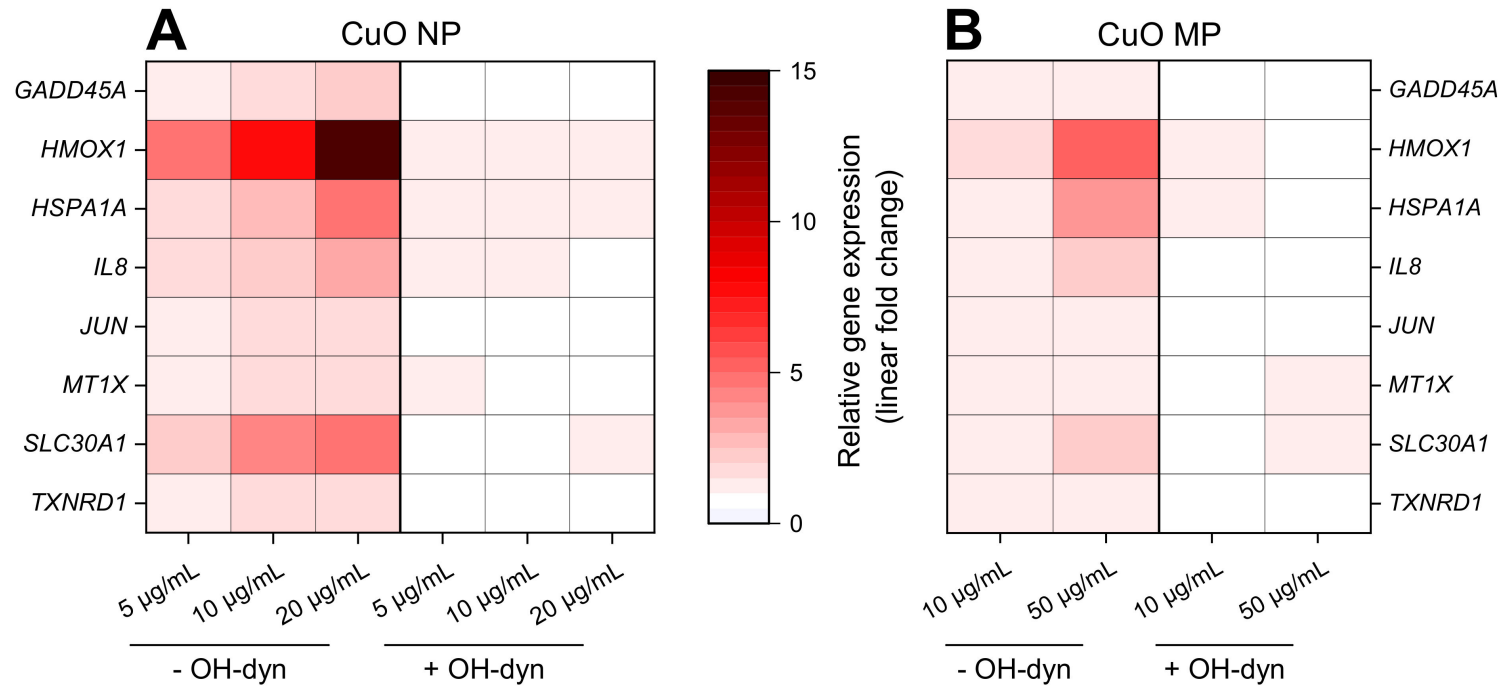

Figure 4. Impact of $\mathrm{CuO} N P(\mathbf{A})$ and $\mathrm{CuO} \mathrm{MP}(\mathbf{B})$ on gene expression patterns related to copper homeostasis, (oxidative) stress, DNA damage and inflammation in the absence or presence of OH-dyn. BEAS-2B cells were treated with the different copper compounds with or without $\mathrm{OH}$-dyn for $8 \mathrm{~h}$. Shown are linear-fold changes of the relative gene expression in a heat map view from mean values of four determinations derived from two independent experiments (expression level of control =1). Exact values including standard deviations are provided in supplementary Table S1.

\subsection{Impact of bafA1}

Gene expression profiling applying $10 \mu \mathrm{g} / \mathrm{mL} \mathrm{CuO} \mathrm{NP}$ or $50 \mu \mathrm{g} / \mathrm{mL} \mathrm{CuO} \mathrm{MP} \mathrm{in} \mathrm{the} \mathrm{absence} \mathrm{or}$ presence of $24 \mathrm{~h}$ bafA1 co-treatment is shown in Figure 5A,B. Again, the most pronounced elevations of gene expression were observed in case of $\mathrm{CuO} N \mathrm{NP}$ when compared to $\mathrm{CuO} \mathrm{MP}$, even though the latter were applied at 5 -fold higher amounts. BafA1 led to a strong, about $50 \%$ reduction of the $\mathrm{CuO}$ NP-mediated induction of the oxidative stress, as well as the copper uptake/homeostasis-related genes HMOX1, HSPA1A, MT1X and MT2A, as well as the DNA damage response gene GADD45A. In case of the pro-inflammatory IL8 gene, results have to be interpreted with caution, due to the high standard deviations and the fact that a 6-fold transcriptional induction was already evident in case of bafA1 alone. Further inductions were observed in case of JUN, the pro-apoptotic PMAIP1, as well as the anti-oxidative associated genes GCLC and TXNRD1; in these cases, baf1A did not substantially alter the respective expression levels. In contrast to $\mathrm{CuO} \mathrm{NP}$, except for HSPA1A and GADD45A, bafA1 did not affect $\mathrm{CuO} \mathrm{MP}$-induced transcriptional changes. 

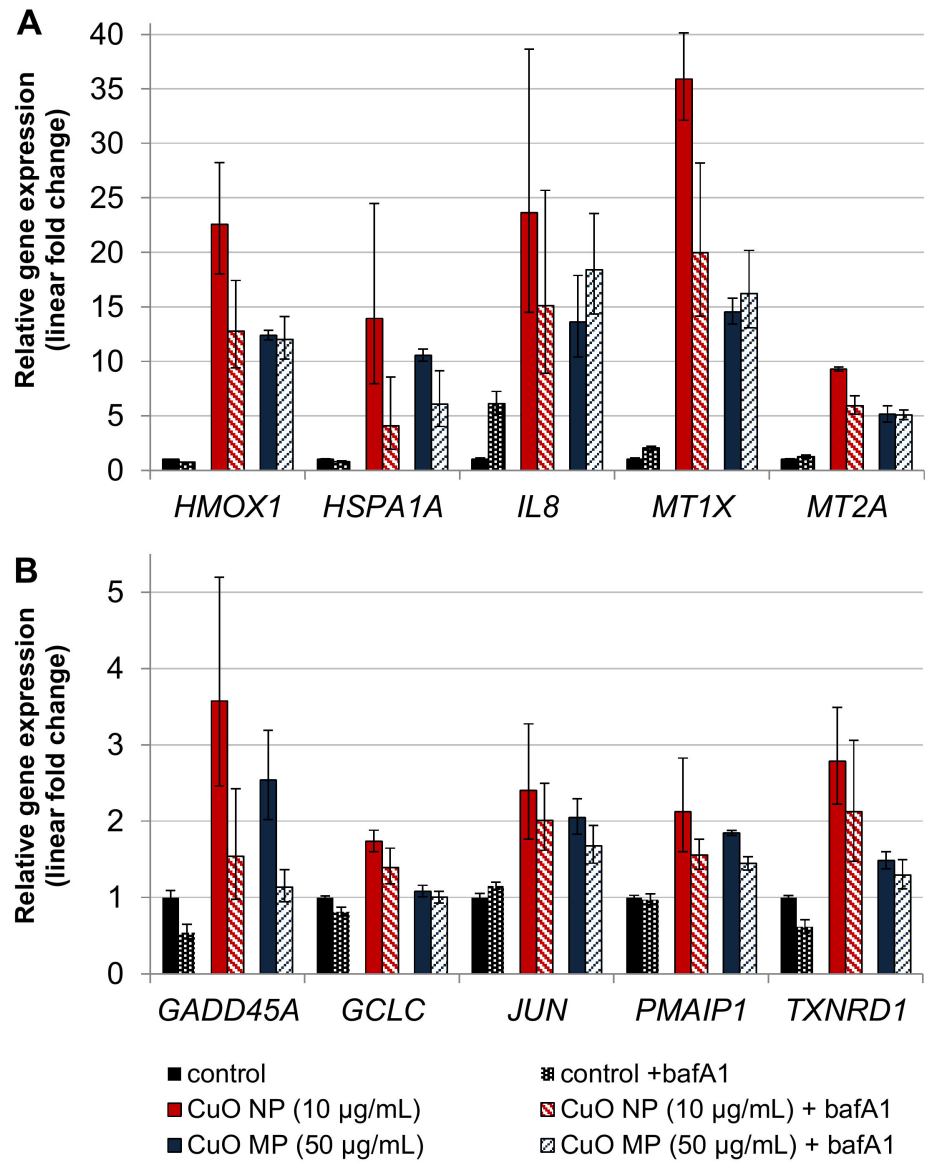

Figure 5. Impact of $\mathrm{CuONP}$ and $\mathrm{CuO} \mathrm{MP}$ on gene expression related to copper uptake, (oxidative) stress and inflammation (A) and DNA damage response, apoptosis, proliferation and anti-oxidative defense (B) in the presence or absence of bafA1. BEAS-2B cells were treated with the different copper compounds with or without bafA1 for $24 \mathrm{~h}$. Shown are mean values of four determinations derived from two independent experiments \pm SD.

\section{Discussion}

Within the present study, the impact of the dynamin-dependent endocytosis inhibitor OH-dyn $[19,20]$, and the vacuolar-type $\mathrm{H}^{+}$-ATPase inhibitor bafA1 attenuating lysosomal acidification $[21,22]$ on cytotoxicity, cellular copper uptake, and especially the modulation of cellular signaling pathways involved in the maintenance of genomic stability by $\mathrm{CuO} \mathrm{NP}$, as compared to $\mathrm{CuO}$ MP, was investigated.

As a prerequisite to estimate the impact of endocytosis, to quantify copper uptake and to discriminate between the cellular effects provoked by copper particle interactions at the outer cell membrane, and those derived from intracellular copper, a post-treatment protocol was applied. Within this procedure, the cells were lysed, and the membranes precipitated by centrifugation. Subsequently, the copper levels were quantified in the soluble cell fraction, excluding copper particles attached to the cell surface, which are not easily detached by washing procedures, thereby avoiding any overestimation of copper uptake. Intracellular copper concentrations were determined by AAS, and calculated based on the cell volume of BEAS 2B cells [8]; no discrimination between copper particles and copper ions is possible by this approach.

In the absence of $\mathrm{OH}$-dyn or bafA1, a pronounced copper accumulation up to $1 \mathrm{mM}$ after $8 \mathrm{~h}$ or $24 \mathrm{~h}$ treatment with $\mathrm{CuO}$ NP was observed, while a lower increase in cellular copper was evident after incubation with $\mathrm{CuOMP}$ or $\mathrm{CuCl}_{2}$, confirming previous observations in this cell line [8]. In case 
of $\mathrm{CuCl}_{2}$, neither $\mathrm{OH}$-dyn nor bafA1 affected the intracellular copper content, thus excluding any unspecific interactions between the inhibitors and copper uptake or homeostasis.

On the contrary, $\mathrm{OH}$-dyn caused a pronounced reduction of intracellular copper accumulation in the case of $\mathrm{CuO} \mathrm{NP}$ and-even more pronounced-in the case of $\mathrm{CuO} \mathrm{MP}$, confirming their uptake via endocytosis. Indeed, dynamin-dependent endocytosis was identified as the main route for the internalization of the $\mathrm{CuO} \mathrm{NP}$, since a reduction of intracellular copper levels of about $50 \%$ was observed; considering the solubility of about $30 \%$ of the $\mathrm{CuO} \mathrm{NP}$ in the cell culture medium (DMEM/FKS) within the $8 \mathrm{~h}$ time frame [7], at least part of the residual increase in intracellular copper is likely to result from extracellularly-released copper ions taken up via respective ion transporters. This assumption is also in agreement with the stronger inhibition of $\mathrm{OH}$-dyn towards $\mathrm{CuO}$ MP uptake, since almost no solubility in the same cell culture medium was observed [7]. Nevertheless, a small impact of dynamin-independent endocytosis not inhibited by OH-dyn cannot be excluded [19,20].

In contrast to $\mathrm{OH}-\mathrm{dyn}$, an impact of the "lysosomal neutralizer" bafA1 was restricted to $\mathrm{CuO}$ $\mathrm{NP}$, diminishing the amount of intracellular copper accumulation to about $60 \%$. On the first sight, this observation is surprising, since this inhibitor would only be expected to inhibit solubilization and copper ion release in the lysosomal environment, and by applying AAS to quantify intracellular copper content, no discrimination between particulate and ionic copper is possible. However, if the lysosomes do not get acidified, the complete endocytic process is disturbed, and the internalized particles remain within the lysosomes, thereby preventing the recycling of protein or lipids essential for this process $[28,29]$. Consequently, endocytosis of the particles is slowed down and reduced during the incubation period of $24 \mathrm{~h}$. The impact of the diminished release of redox-reactive copper ions by $\mathrm{CuONP}$ in less acidic lysosomes became obvious when considering the other endpoints investigated within this study. Thus, co-treatment with bafA1 strongly reduced the cytotoxicity of CuO NP and prevented the $\mathrm{CuO}$ NP-induced GSH depletion after $2 \mathrm{~h}$, indicating that oxidative stress occurs due to increased intracellular levels of copper ions. In support of this theory, an enhanced toxicity of $\mathrm{CuO} \mathrm{NP}$ due to the increased intracellular solubility in an acidic environment resulting in elevated levels of copper ions, was also reported by other working groups [30,31]. In contrast to CuO NP, no impact of bafA1 was observed in case of $\mathrm{CuO} \mathrm{MP}$, in agreement with the low solubility of $\mathrm{CuO} \mathrm{MP}$ in artificial lysosomal fluid (ALF), as compared to CuO NP published previously [7].

In the absence of either inhibitor, gene expression profiling after $8 \mathrm{~h}$ treatment with $\mathrm{CuO} N \mathrm{~N}$ revealed a strictly concentration-dependent induction of mainly so-called early response genes, namely MT1X, SLC30A1, HMOX1, HSPA1A, GADD45A, IL8, JUN, and TXNRD1, revealing elevated intracellular copper levels, the induction of oxidative stress, inflammation, DNA damage, inflammatory response, as well as an activation of the transcription factors AP-1 and MTF-1 [32-38]. A similar pattern was observed in case of $\mathrm{CuO}$ MP, however, far less pronounced. These observations highly corresponded to the previously published, detailed gene expression analyses with the same copper particles [8]. However, co-treatment with OH-dyn completely diminished the CuO NP- as well as CuO MP-induced gene inductions. This indicates that the observed changes in gene expression can be exclusively assigned to intracellular copper, with no impact of particle interactions with the outer membrane.

Gene expression analyses after $24 \mathrm{~h}$ exposure to $\mathrm{CuO}$ particles revealed almost the same pattern as compared to the $8 \mathrm{~h}$ treatment; however, respective modulations were more pronounced. In the presence of bafA1, CuO NP-mediated gene inductions were reduced to a high degree by bafA1 in the case of the ROS-inducible HMOX1 and HSPA1A, genotoxic stress-inducible GADD45A, pro- inflammatory IL8, as well as the copper uptake related MT1X and MT2A. Thus, with respect to the modulation of those stress responsive genes, the acidification of lysosomes, and in consequence the release of copper ions, were of major importance, signaling elevated levels of ROS, with the consequence of oxidative and genotoxic stress, as well as inflammatory effects [34,36-39]. These protective interactions in the presence of bafA1 correspond to the reduced intracellular copper accumulation, the prevented GSH-depletion and reduced cytotoxicity of $\mathrm{CuO} \mathrm{NP}$ in the presence of bafA1 on the functional level. 
On the other hand, no impact of bafA1 was observed concerning the transcriptional modulation of the pro-apoptotic gene PMAIP1, the proto-oncogene coding JUN assigned to AP-1 activation [32] and the anti-oxidative genes GCLC and TXNRD1 mainly induced by activated Nrf2 [40]. Thus, the amount of intracellular copper and ROS generation in the presence of bafA1 seemed still sufficient for the activation of these genes, which may again be explained by uptake of copper ions released extracellularly from the $\mathrm{CuO} \mathrm{NP}$, but also from low level intracellular copper ion release in the presence of bafA1. In case of $\mathrm{CuO} \mathrm{MP}$, except for HSPA1A and GADD45A, no impact of bafA1 on gene expression alterations was observed, in agreement with its low solubility, even in the acidic lysosomal environment.

\section{Conclusions}

Taken together, our findings strongly support the leading role of the dynamin-dependent endocytosis and lysosomal acidification on $\mathrm{CuO}$ NP-induced cellular toxicity, provoking a distinct release of redox-active copper ions, and causing highly elevated intracellular copper levels. Toxicity profiles correspond to the induction of disturbed metal homeostasis, oxidative and genotoxic stress, as well as the activation of redox-sensitive transcription factors, thereby confirming previous investigations. They exclude the interactions of $\mathrm{CuO}$ NP with the outer cell membrane as contributing factors to their toxicity. In consequence, the results add strong support to the proposed Trojan horse-type mechanism accounting for $\mathrm{CuO}$ NP toxicity. Furthermore, they support the impact of particle size on $\mathrm{CuO}$-induced cellular effects, also as a basis for toxicological risk assessment.

Supplementary Materials: The following are available online at http://www.mdpi.com/2079-4991/10/4/679/s1, Figure S1: Supporting information on the impact of $\mathrm{OH}-\mathrm{dyn}$ on the expression of genes modulated by the copper compounds, Table S1: supporting information on the impact of $\mathrm{CuO} N \mathrm{NP}(\mathrm{A})$ and $\mathrm{CuO} \mathrm{MP}(\mathrm{B})$ on gene expression levels related to copper homeostasis, (oxidative) stress, DNA damage and inflammation in the absence or presence of OH-dyn. BEAS-2B cells were treated with the different copper compounds with or without $\mathrm{OH}$-dyn for $8 \mathrm{~h}$.

Author Contributions: Conceptualization, A.H. and B.M.S..; methodology, B.M.S. and A.H.; validation, B.M.S. and A.H.; formal analysis, B.M.S.; investigation, B.M.S. and W.H.; resources, A.H.; data curation, B.M.S. and A.H.; writing-original draft preparation, B.M.S.; writing-review and editing, A.H., B.M.S and W.H.; visualization, B.M.S. and W.H.; supervision, A.H.; project administration, A.H.; funding acquisition, A.H. and B.M.S. All authors have read and agreed to the published version of the manuscript.

Funding: This work was supported by the German Research Council DFG - Deutsche Forschungsgemeinschaft (Excellence Initiative KIT) and by Scholarship Graduate Funding for BMS from the German States Program (LGF) - Landesgraduiertenförderung.

Acknowledgments: The authors would like to thank Matthias Hufnagel for his support in the graphical presentation of the gene expression profiles.

Conflicts of Interest: The authors declare no conflict of interest.

\section{Abbreviations}

AAF: Artificial alveolar fluid; ALF: Artificial lysosomal fluid; AP-1: activator protein 1; bafA1: bafilomycin A1; BET: Brunauer-Emmett-Teller analysis; CDKN1A: cyclin-dependent kinase inhibitor 1A; Cq: Quantitation cycle; $\mathrm{CuCl}_{2}$ : Copper chloride, $\mathrm{CuO}$ MP: Copper oxide microparticles; CuO NP: Copper oxide nanoparticles, DLS: Dynamic light scattering; DR5: death receptor 5; EDX: Energy-dispersive X-ray spectroscopy; GADD45A: growth arrest and DNA-damage-inducible, alpha; GF-AAS: Graphite furnace atomic absorption spectrometry; GSH: Glutathione; hCTR1: high-affinity copper transporter 1; HMOX1: heme oxygenase; HSPA1A: heat shock 70kDa protein 1A; ICP-MS: Inductively coupled plasma mass spectrometry; IL8: interleukine 8; MT1X: metallothionein 1X; MT2A: metallothionein 2A; MTF-1: Metal-regulatory transcription factor 1; Nrf2: Nuclear factor (erythroid-derived 2)-like 2; OH-dyn: hydroxyl-dynasore; PMAIP1: phorbol-12-myristate-13-acetate-induced protein 1; ROS: Reactive oxygen species; RT-qPCR: Reverse transcription quantitative polymerase chain reaction; SCL30A: solute carrier family 30 (zinc transporter), member 1; SEM: Scanning electron microscopy; SOD: Superoxide dismutase; TEM: Transmission electron microscopy; TNFRSF10B: tumor necrosis factor receptor superfamily, member 10b; TXNRD1: thioredoxin reductase 1;.V-ATPase: vacuolar type $\mathrm{H}^{+}$-ATPase; ZP: Zeta potential; ZnT-1: zinc transporter 1 


\section{References}

1. Chang, Y.-N.; Zhang, M.; Xia, L.; Zhang, J.; Xing, G. The toxic effects and mechanisms of CuO and ZnO nanoparticles. Materials 2012, 5, 2850-2871. [CrossRef]

2. Cronholm, P.; Karlsson, H.L.; Hedberg, J.; Lowe, T.A.; Winnberg, L.; Elihn, K.; Wallinder, I.O.; Moeller, L. Intracellular Uptake and Toxicity of $\mathrm{Ag}$ and $\mathrm{CuO}$ Nanoparticles: A Comparison Between Nanoparticles and their Corresponding Metal Ions. Small 2013, 9, 970-982. [CrossRef] [PubMed]

3. Fahmy, B.; Cormier, S.A. Copper oxide nanoparticles induce oxidative stress and cytotoxicity in airway epithelial cells. Toxicol. In Vitro 2009, 23, 1365-1371. [CrossRef] [PubMed]

4. Karlsson, H.L.; Cronholm, P.; Gustafsson, J.; Moller, L. Copper oxide nanoparticles are highly toxic: A comparison between metal oxide nanoparticles and carbon nanotubes. Chem. Res. Toxicol. 2008, 21, 1726-1732. [CrossRef]

5. Karlsson, H.L.; Gustafsson, J.; Cronholm, P.; Moller, L. Size-dependent toxicity of metal oxide particles-A comparison between nano- and micrometer size. Toxicol. Lett. 2009, 188, 112-118. [CrossRef] [PubMed]

6. Midander, K.; Cronholm, P.; Karlsson, H.L.; Elihn, K.; Moeller, L.; Leygraf, C.; Wallinder, I.O. Surface characteristics, copper release, and toxicity of nano- and micrometer-sized copper and copper(II) oxide particles: A cross-disciplinary study. Small 2009, 5, 389-399. [CrossRef] [PubMed]

7. Semisch, A.; Ohle, J.; Witt, B.; Hartwig, A. Cytotoxicity and genotoxicity of nano-And microparticulate copper oxide: Role of solubility and intracellular bioavailability. Part. Fibre Toxicol. 2014, 11, 1-16. [CrossRef] [PubMed]

8. Strauch, B.M.; Niemand, R.K.; Winkelbeiner, N.L.; Hartwig, A. Comparison between micro- and nanosized copper oxide and water soluble copper chloride: Interrelationship between intracellular copper concentrations, oxidative stress and DNA damage response in human lung cells. Part Fibre Toxicol. 2017, 14, 28. [CrossRef]

9. Limbach, L.K.; Wick, P.; Manser, P.; Grass, R.N.; Bruinink, A.; Stark, W.J. Exposure of engineered nanoparticles to human lung epithelial cells: Influence of chemical composition and catalytic activity on oxidative stress. Environ. Sci. Technol. 2007, 41, 4158-4163. [CrossRef]

10. Jomova, K.; Baros, S.; Valko, M. Redox active metal-induced oxidative stress in biological systems. Transit. Met. Chem. 2012, 37, 127-134. [CrossRef]

11. Hartwig, A. Metal interaction with redox regulation: An integrating concept in metal carcinogenesis? Free Radic. Biol. Med. 2013, 55, 63-72. [CrossRef] [PubMed]

12. Marano, F.; Hussain, S.; Rodrigues-Lima, F.; Baeza-Squiban, A.; Boland, S. Nanoparticles: Molecular targets and cell signalling. Arch. Toxicol. 2011, 85, 733-741. [CrossRef] [PubMed]

13. Fischer, B.M.; Neumann, D.; Piberger, A.L.; Risnes, S.F.; Koeberle, B.; Hartwig, A. Use of high-throughput RT-qPCR to assess modulations of gene expression profiles related to genomic stability and interactions by cadmium. Arch. Toxicol. 2016, 90, 2745-2761. [CrossRef] [PubMed]

14. Canton, I.; Battaglia, G. Endocytosis at the nanoscale. Chem. Soc. Rev. 2012, 41, 2718-2739. [CrossRef] [PubMed]

15. Lunov, O.; Zablotskii, V.; Syrovets, T.; Roecker, C.; Tron, K.; Nienhaus, G.U.; Simmet, T. Modeling receptor-mediated endocytosis of polymer-functionalized iron oxide nanoparticles by human macrophages. Biomaterials 2010, 32, 547-555. [CrossRef] [PubMed]

16. Sahay, G.; Alakhova, D.Y.; Kabanov, A.V. Endocytosis of nanomedicines. J. Control. Release 2010, 145, $182-195$. [CrossRef]

17. Wang, Z.Y.; Li, N.; Zhao, J.; White, J.C.; Qu, P.; Xing, B.S. CuO Nanoparticle Interaction with human epithelial cells: cellular uptake, location, export, and genotoxicity. Chem. Res. Toxicol. 2012, 25, 1512-1521. [CrossRef]

18. Zhang, S.; Li, J.; Lykotrafitis, G.; Bao, G.; Suresh, S. Size-dependent endocytosis of nanoparticles. Adv. Mater. 2009, 21, 419-424. [CrossRef]

19. Macia, E.; Ehrlich, M.; Massol, R.; Boucrot, E.; Brunner, C.; Kirchhausen, T. Dynasore, a cell-permeable inhibitor of dynamin. Dev. Cell 2006, 10, 839-850. [CrossRef]

20. McCluskey, A.; Daniel, J.A.; Hadzic, G.; Chau, N.; Clayton, E.L.; Mariana, A.; Whiting, A.; Gorgani, N.N.; Lloyd, J.; Quan, A.; et al. Building a better dynasore: The dyngo compounds potently inhibit dynamin and endocytosis. Traffic 2013, 14, 1272-1289. [CrossRef] 
21. Bowman, E.J.; Siebers, A.; Altendorf, K. Bafilomycins: A class of inhibitors of membrane ATPases from microorganisms, animal cells, and plant cells. Proc. Natl. Acad. Sci. USA 1988, 85, 7972-7976. [CrossRef] [PubMed]

22. Yoshimori, T.; Yamamoto, A.; Moriyama, Y.; Futai, M.; Tashiro, Y. Bafilomycin A1, a specific inhibitor of vacuolar-type $\mathrm{H}(+)$-ATPase, inhibits acidification and protein degradation in lysosomes of cultured cells. J. Biol. Chem. 1991, 266, 17707-17712. [PubMed]

23. Livak, K.J.; Schmittgen, T.D. Analysis of relative gene expression data using real-time quantitative PCR and the 2- $\Delta \Delta \mathrm{CT}$ method. Methods 2001, 25, 402-408. [CrossRef] [PubMed]

24. Tietze, F. Enzymic method for determination of nanogram amounts of total and oxidized glutathione: Applications to mammalian blood and other tissues. Anal. Biochem. 1969, 27, 502-522. [CrossRef]

25. Stopford, W.; Turner, J.; Cappellini, D.; Brock, T. Bioaccessibility testing of cobalt compounds. J. Environ. Monit. 2003, 5, 675-680. [CrossRef]

26. Midander, K.; Wallinder, I.O.; Leygraf, C. In vitro studies of copper release from powder particles in synthetic biological media. Environ. Pollut. 2007, 145, 51-59. [CrossRef]

27. Semisch, A.; Hartwig, A. Copper Ions Interfere with the Reduction of the Water-Soluble Tetrazolium Salt-8. Chem. Res. Toxicol. 2014, 27, 169-171. [CrossRef]

28. Maxfield, F.R.; McGraw, T.E. Endocytic recycling. Nat. Rev. Mol. Cell Biol. 2004, 5, 121-132. [CrossRef]

29. Van Weert, A.W.M.; Dunn, K.W.; Geuze, H.J.; Maxfield, F.R.; Stoorvogel, W. Transport from late endosomes to lysosomes, but not sorting of integral membrane proteins in endosomes, depends on the vacuolar proton pump. J. Cell Biol. 1995, 130, 821-834. [CrossRef]

30. Moschini, E.; Gualtieri, M.; Colombo, M.; Fascio, U.; Camatini, M.; Mantecca, P. The modality of cell-particle interactions drives the toxicity of nanosized $\mathrm{CuO}$ and $\mathrm{TiO}_{2}$ in human alveolar epithelial cells. Toxicol. Lett. 2013, 222, 102-116. [CrossRef]

31. Studer, A.M.; Limbach, L.K.; Van, D.L.; Krumeich, F.; Athanassiou, E.K.; Gerber, L.C.; Moch, H.; Stark, W.J. Nanoparticle cytotoxicity depends on intracellular solubility: Comparison of stabilized copper metal and degradable copper oxide nanoparticles. Toxicol. Lett. 2010, 197, 169-174. [CrossRef] [PubMed]

32. Angel, P.; Hattori, K.; Smeal, T.; Karin, M. The jun proto-oncogene is positively autoregulated by its product, Jun/AP-1. Cell 1988, 55, 875-885. [CrossRef]

33. Gozzelino, R.; Jeney, V.; Soares, M.P. Mechanisms of cell protection by heme oxygenase-1. Annu. Rev. Pharmacol. Toxicol. 2010, 50, 323-354. [CrossRef] [PubMed]

34. Hoffmann, E.; Dittrich-Breiholz, O.; Holtmann, H.; Kracht, M. Multiple control of interleukin-8 gene expression. J. Leukoc. Biol. 2002, 72, 847-855. [PubMed]

35. Marr, S.K.; Pennington, K.L.; Marr, M.T. Efficient metal-specific transcription activation by Drosophila MTF-1 requires conserved cysteine residues in the carboxy-terminal domain. Biochim. Biophys. Acta Gene Regul. Mech. 2012, 1819, 902-912. [CrossRef] [PubMed]

36. Pirkkala, L.; Nykanen, P.; Sistonen, L. Roles of the heat shock transcription factors in regulation of the heat shock response and beyond. FASEB J. 2001, 15, 1118-1131. [CrossRef] [PubMed]

37. Sims, H.I.; Chirn, G.-W.; Marr, M.T., II. Single nucleotide in the MTF-1 binding site can determine metal-specific transcription activation. Proc. Natl. Acad. Sci. USA 2012, 109, 16516-16521. [CrossRef]

38. Zhan, Q. Gadd45a, a p53- and BRCA1-regulated stress protein, in cellular response to DNA damage. Mutat. Res. Fundam. Mol. Mech. Mutagen. 2005, 569, 133-143. [CrossRef]

39. Ryter, S.W.; Choi, A.M.K. Heme oxygenase-1: Redox regulation of a stress protein in lung and cell culture models. Antioxid. Redox Signal. 2005, 7, 80-91. [CrossRef]

40. Kobayashi, M.; Yamamoto, M. Molecular Mechanisms Activating the Nrf2-Keap1 Pathway of Antioxidant Gene Regulation. Antioxid. Redox Signal. 2005, 7, 385-394. [CrossRef]

(C) 2020 by the authors. Licensee MDPI, Basel, Switzerland. This article is an open access article distributed under the terms and conditions of the Creative Commons Attribution (CC BY) license (http://creativecommons.org/licenses/by/4.0/). 